\title{
ACCEPTANCE OF TECHNOLOGY IN ONLINE TRAINING BY HUMAN RESOURCE MANAGEMENT TRAINING PARTICIPANTS DURING COVID 19
}

\author{
Marcia Martha, Djamalludin Ancok, Nilam Widyarini, \\ Mohammad lqbal Gunadarma University \\ Jl. Margonda Raya No 100. Depok. Jawa Barat. Indonesia
}

\begin{abstract}
Covid-19 has forced many agendas to be carried out online, including human resource training activities. Training cannot be separated from various kinds of problems, including the methods used in training. The result of previous studies revealed the fact that very few learning activities are carried out online, because of the perception that will be difficult to learn when doing it online. This is of course related to how each individual accepts technology. This study aims to develop and construct a theoretical model of technology acceptance based on the Theory Acceptance Model (TAM), which is the development of Theory Planned Behavior (TPB) for online HR training participants and test it based on field data. The respondents of this study consisted of 181 people with the criteria that they had attended online human resource management training and were members of an organization. Data was collected using a questionnaire. There are 4 questionnaires used in this study, namely: actual use scale, behavior intention scale, perceived ease of use scale, and perceived usefulness scale. The data analysis of this study uses path analysis with the help of the Amos 24 and SPSS 28 programs. The result of this study indicates that the model proposed in this study is in accordance with the theoretical concepts with empirical data. This is evidenced by various criteria such as the Chi-Square value of 1.089, the probability value of 0.947 , the GFI value of 1.0 , the TLI value of 1.0, and the RMSEA value of 0.050. This shows that perceived convenience (PU), perceived usefulness (PE), and behavioral intention (BI) affect technology use behavior (AU).
\end{abstract}

Keywords: technology use behavior, behavioral intention, perceived convenience, perceived usefulness

\section{INTRODUCTION}

Coronavirus disease 2019 which is abbreviated as COVID-19 is a disease designated by the

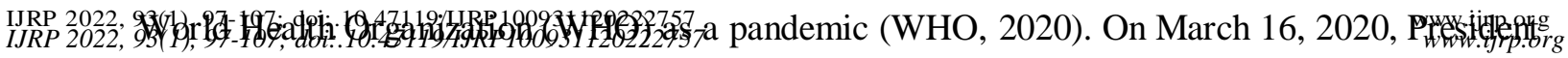
Joko Widodo adopted a policy to temporarily close schools, places of worship, and asked several 
business sectors to start working from home. This is intended to eliminate crowds of people in one place which can be a source of the spread of COVID-19 (Ihsannudin, 2020). Schools and universities implement E-learning as a step to replace face-to-face online learning and teaching activities. E-learning is the application of technology and internet networks to carry out the education or learning process (Prawiradilaga, Ariani \& Handoko, 2013).

For a long time, e-learning has existed as a form of technological progress. However, in reality, individuals do not use the internet optimally for learning purposes. This is illustrated by the results of research conducted by Wirasti (in Prawiradilaga, 2013) which states that the internet as a learning medium is only used as much as $24 \%$. This figure is far below compared to the use of the internet to communicate (46\%) and play games (38\%). Until the emergence of covid-19, until e-learning became popular and was used almost $100 \%$ in formal, informal and non-formal learning and teaching activities.

Prior to COVID-19, Prawiradilaga (2013) made an analysis of why people do not want to use internet technology for learning. One of the reasons found is that many people still perceive that using the internet for learning purposes is difficult. Due to the perception of the difficulty of using the internet, people do not have the intention to use computers and the internet for online learning purposes. Even things like this still happen in big cities. In 2020, researchers conducted a pilot study at one of the Human Resource Management (HRM) training institutions in Jakarta. At that time, the training institute was preparing an online training program with a duration of 14 working days for HRM training. The training uses a web-based system where participants are given an account and after that the trainee can log into the account to take part in the training provided. The account contains materials that can be accessed using self-study methods and also contains assignments from training mentors that can be done by training participants. This form of learning is called asynchronous learning, which is an online learning process that provides teaching materials and indirect assignments.

There are many people who agree with online learning, but disagree with the asynchronous learning model because it is considered more difficult. To overcome this, training institutions work around this by using an online learning process with the synchronous learning method, namely direct online learning using teleconferencing applications, such as zoom meetings or google meetings. This shows that the problems found by Prawiradilaga in 2013 will still occur in 2020. There are still many people who have not been able to use technology for educational purposes. Such a phenomenon occurs due to the lack of people's ability to accept a form of technology. Teo (2011) defines technology acceptance as the user's desire to use technology to support the work or task that has been designed. 
Research conducted by Hartwick and Barki (1994 in Jogiyanto, 2007) when testing the theory of reason action behavior showed that the influence of attitude towards the use of a system was found to be significant but negative. This result is considered unreasonable, because the higher the attitude of people towards the use of the system, the lower the use of the system. These problems can be answered with the TAM concept, which is a technology system that failed to be implemented due to the lack of intention to use it (Jogiyanto, 2007). Furthermore, it is said that the intention to behave (behavior intention) and a behavior are two different things. Intentions are not yet in the form of behavior, while behavior is a real action taken. Behavioral intentions will predict his behavior. Sheppard (in Jogiyanto, 2007) tried to do a meta-analysis of 86 studies. The result shows that there is an average correlation of 0.54 points between intentions and behavior. In the same year, Ajzen also published the results of his analysis of the relationship between intention and behavior. The result shows something more significant.

Furthermore, TAM argues that the behavioral intention to accept technology is determined by two constructs, namely: user perceptions of the usefulness and ease of using technology (Siregar, 2011). Perceived of usefulness (PU) is an individual's belief that a technology will improve its performance. Meanwhile, Perceived of Ease Usefulness (PE) is an individual's belief that the technology is easy to use so that it does not require hard work to be free from difficulties (Fatmawati, 2015). Research conducted by Saade, Nebebe, and Tan (2007) and Tangke (2004) found that perceived ease of use has a positive relationship with perceived usefulness.

Previous studies have shown that if someone feels the convenience of an information technology, then someone will want to use the information technology (Davis, 1989; Igbaria, 1995; Adam et al., 1992; Venkatesh and Davis, 2000; Malhotra and Galletta, 1999; Tangke, 2004; Saade, Nebebe, and Tan 2007). Meanwhile, research conducted by Klopping and McKinney (2004) found that a person's desire to use a system is influenced by perceived usefulness, where someone feels the benefits of the system used, the person wants to use the system. Other researchers found a positive relationship between perceived usefulness and the intention to use a system (Malhotra and Galletta, 1999; Saade, Nebebe and Tan, 2007).

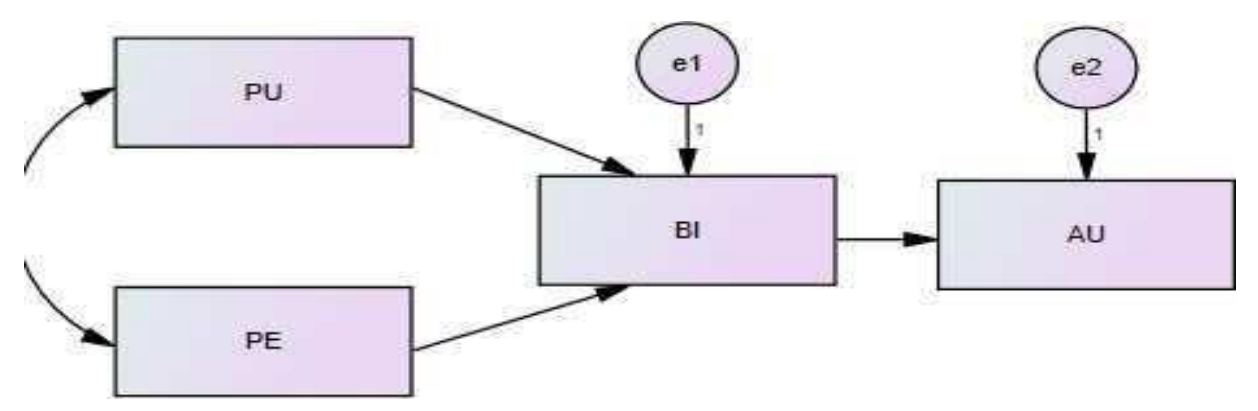


Figure 1. The proposed model

description :
AU : Actual Use
$\mathrm{BI}$ : Behavioral Intention
PU : Perceived Usefulness
PE : Perceived Ease of Use

The phenomenon of technology acceptance among online HR training participants in Indonesia cannot be separated from the user's perception that the technology used is easy and useful. Technology acceptance of online HRM training participants in Indonesia still needs to be tested on a theoretical model developed with reference to the Technology Acceptance Model (TAM) which is supported by data in the field. The researcher assumes that the behavior of accepting technology is influenced by the perception of usefulness and the perception of convenience, with mediating the intention to behave in accepting technology. The major hypothesis in this study is the perception of convenience and the perceived usefulness of forming and constructing a theoretical model regarding the acceptance of technology in online training participants and the relationship between the variables in the model fit with the data.

In accordance with the proposed model, the researcher proposes two minor hypotheses in this study, namely: there is an indirect effect of perceived convenience on behavior using technology through behavioral intentions to accept technology, and there is an indirect effect of perceived usefulness on behavior using technology through behavioral intention to accept technology.

\section{RESEARCH METHOD}

In accordance with the purpose of this study, namely to develop and construct a theoretical model of technology acceptance for online HR training participants and test it based on field data, the researchers used non-experimental quantitative research methods. Quantitative research method is an analysis of numerical data that is processed by statistical methods (Azwar, 2013). The population of this research is people who are involved in the field of HR in an organization. The sampling technique in this research is using purposive sampling, where the researcher determines a number of characteristics that are in accordance with the objectives of this study. The characteristics of the sample in this study were research subjects who had attended online 
HRM training during the COVID-19 pandemic, either through their workplace organizations or through HRM training institutions in Indonesia. Another criterion is that the sample in this study uses blended learning training methods (asynchronous and synchronous) and the sample of this study is also included in an organization either as staff, supervisor or manager.

Technology acceptance behavior in this study was measured using a scale compiled by Straub (1995), namely behavior based on perceptions of the amount of time spent using technology, and based on perceptions of the intensity of technology use (very often, often and rarely): technology to complete my training assignments." Meanwhile, intention to use technology, perceived convenience, and perceived usefulness in this study were measured using a scale compiled by Davis (1989). The form of the scale in this study is Likert with a range of answer choices from 1 to 5.1 for a very inappropriate answer, 2 for an inappropriate answer, 3 for a neutral answer, 4 for an appropriate answer and 5 for a very appropriate answer. Technology acceptance behavior in this study was measured using a scale compiled by Straub (1995), namely behavior based on perceptions of the amount of time spent using technology, and based on perceptions of the intensity of technology use (very often, often and rarely): technology to complete my training assignments." Meanwhile, intention to use technology, perceived convenience, and perceived usefulness in this study were measured using a scale compiled by Davis (1989). The form of the scale in this study is Likert with a range of answer choices from 1 to 5.1 for a very inappropriate answer, 2 for an inappropriate answer, 3 for a neutral answer, 4 for an appropriate answer and 5 for a very appropriate answer.

\section{RESULT AND DISCUSSION}

The questionnaires in this study were distributed via google form, due to the pandemic. This research was conducted from April 20 to September 1, 2021, and 181 were collected. The samples in this study were from various training institutions and organizations in Indonesia. All samples in this study used online training methods, both asynchronously via the website and email and synchronously using google meet and zoom meetings.

The validity test in this study uses the confirmatory factor analysis (CFA) technique, in which Widhiarso (2011) says that in the CFA technique, the chi-square value produced is the weight of the validity of the measuring instrument. Furthermore, Ferdinand (2000) said that the acceptable factor loading for CFA is 0.40 . In this study, the value of the loading weight of the two measuring instruments moves from 0.604 to 0.885 . 
Meanwhile, for the discriminatory power of the measuring instrument items in this study, none of the item items failed. The following table 1 describes the result of the item discriminatory power and reliability of each measuring instrument.

Table 1. Test of Item Discrimination Power, Validity, and Reliability of Measuring Instruments

\begin{tabular}{lccc}
\hline Variabel & $\begin{array}{c}\text { Loading } \\
\text { Weight }\end{array}$ & $\begin{array}{c}\text { Item Discrimination } \\
\text { Power Range }\end{array}$ & Reliability Value \\
\hline $\begin{array}{l}\text { Behavior of accepting } \\
\text { technology }\end{array}$ & $0,643-0,885$ & $0,665-0,781$ & 0,798 \\
$\begin{array}{l}\text { Intention to Use } \\
\text { Technology }\end{array}$ & $0,604-0,819$ & $0,587-0,767$ & 0,830 \\
Perceived of Usefulness & $0.701-0.875$ & $0.496-0.759$ & 0.815 \\
Perceived Ease of Use & $0.634-0.858$ & $0,570-0,825$ & 0,867 \\
\end{tabular}

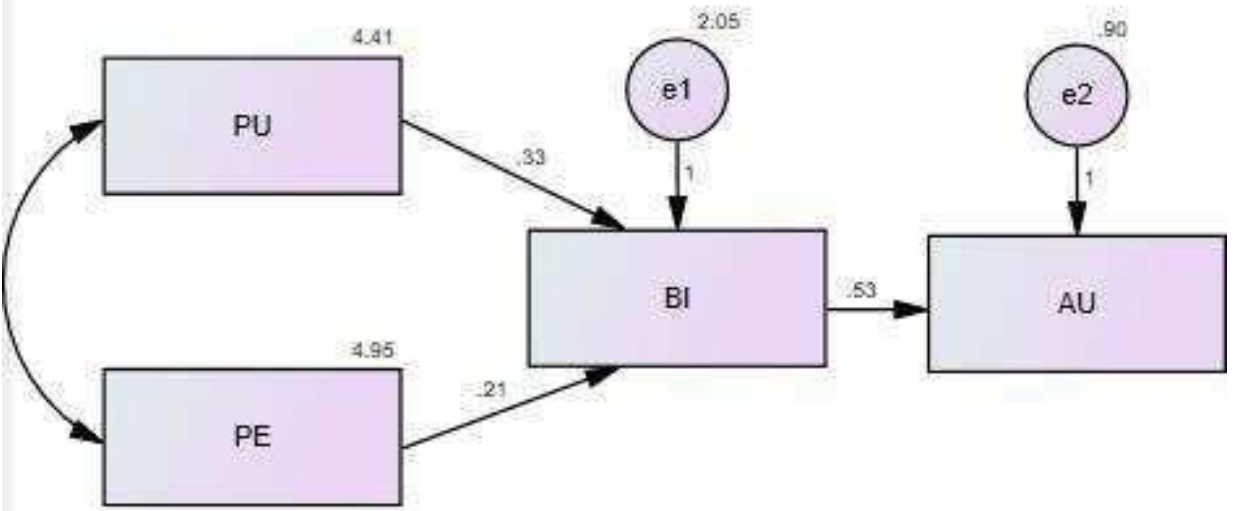

Figure 2. Research model

Description :
AU : Actual Use
BI : Behavioral Intention
PU : Perceived Usefulness
PE : Perceived Ease of Use 
Table 2. Conformity of Values with Criteria for Goodness of Fit Theoretical Research

\section{Model}

\begin{tabular}{llll}
\hline Criteria & Provision & Result & Description \\
\hline Chi-Square & As small as & 2.089 & Fit \\
& possible & & \\
p-value & $\geq 0,05$ & 0.947 & Fit \\
RMSEA & $\leq 0.08$ & 0.050 & Fit \\
GFI & $\geq 0,9$ & 1.0 & Fit \\
TLI & $\geq 0,9$ & 1.0 & Fit \\
\hline
\end{tabular}

The test results for the major hypothesis show that the technology acceptance model is supported by field data. Behavior using technology (AU) can be explained by behavioral intentions (BI), perceived usefulness (PU), and perceived ease (PE). Figure 1 explains that the major hypotheses stating perceived convenience (PE), perceived usefulness (PU), and behavioral intentions (BI) form and construct a theoretical model of technology acceptance behavior (AU) in online HRM training participants and the relationship between variables in the model fits the data.

Table 3. Structural Equation Causality Test and Effect of Research Variables

\begin{tabular}{lllcl}
\hline Lane & $\mathrm{P}$ & Cut velue & Regression & Conclusion \\
\hline $\mathrm{PE} \rightarrow \mathrm{BI} \rightarrow \mathrm{AU}$ & 0.01 & $\leq 0.05$ & 0.325 & Accepted \\
$\mathrm{PU} \rightarrow \mathrm{BI} \rightarrow \mathrm{AU}$ & 0.01 & $\leq 0.05$ & 0.215 & Accepted
\end{tabular}

The result of the causality test of the structural model between paths can be seen that the assumptions of the minor hypotheses of the research model are as follows:

1. Minor hypothesis 1 is accepted. The result proves that the indirect effect of perceived ease of accepting technology through behavioral intentions with a p-value of $0.01<0.05$. Thus, behavioral intention acts as a mediator between perceived ease of use and technology acceptance behavior in online HRM training participants.

2. Minor hypothesis 2 is accepted. The result proves that the indirect effect of perceived usefulness on the behavior of accepting technology through behavioral intentions with a p-value of $0.01<0.05$. Thus, behavioral intention acts as a mediator between perceived usefulness and technology acceptance behavior in online HRM training participants.

The result of this study found that the behavior of using technology in online HR training participants can be influenced by behavior intention. While the intention to behave using a 
technology is formed because of the perception that technology is easy and useful (Saade, et al, 2007).

The results of this study found that the behavior of using technology in online HR training participants can be influenced by behavior intention. While the intention to behave using a technology is formed because of the perception that technology is easy and useful (Saade, et al, 2007).

A training held by an organization has gone through a long deliberation. A training is held not only because of the need for a new competency that is expected to be mastered by employees to work more efficiently. However, training also brings other positive impacts to the organization, one of which is the organization and the people in it can recognize the times and what they have to do in order to adapt to these developments. The COVID-19 pandemic has forced training to undergo a lot of changes, one of which is done online. This is intended to stem the spread of the corona virus outbreak. On the other hand, online training also brings positive impacts, such as lower training prices and organizations having more choices for training service providers from other cities, who may be perceived as having more credibility.

The proficiency of online training participants in HRM training in using technology is an absolute requirement to be able to take part in the training. This is because online training relies on the internet as the only mode of teaching and learning activities. If the trainees are not proficient in using internet technology, it will certainly have implications for poor training results. A further impact that is predicted to arise if the results of the training are not good is that the performance of the employees involved in the training will be less good.

In an initial study, researchers found that many prospective online trainees would refuse training if it was carried out only asynchronously (without face-to-face with the tutor). This is because the prospective participants perceive that training with this method will be more difficult not only in understanding the material, but also difficult to access and use features on the internet to support the training. Therefore, the prospective trainees propose that the training be carried out using balanced learning, namely a training method that combines asynchronous methods with synchronous methods (using online meeting applications such as: zoom meetings, so that they can meet face-to-face with tutors) in the hope of perceiving the difficulty of using training technology online is lessen or even disappeared.

Ibrahim, et al (2017) say that individuals who have experience in using easy technology and benefit from the technology will grow the intention to accept the technology, which in turn will predict the actual technology use behavior. This is in line with the result of previous studies which show that if someone feels the convenience and usefulness of an information technology, someone is eager to use the information technology (Davis, 1989; Igbaria, 1995; Adam et al., 
1992; Venkatesh, 1989). and Davis, 2000; Malhotra and Galletta, 1999; Tangke, 2004; Klopping and McKinney, 2004; Saade, Nebebe, and Tan 2007; Scherer, Siddiq, Tondelur, 2019; Tahini, Hone, Liu, 2013; Lee, Hsieh, Ma , 2011; Devi \& Suartana, 2014; Handayani \& Harsono, 2016; Ibrahim, Leng, Yusoff, Samy, Mazrom, Rizman 2017; Alharbi \& Drew, 2019).

\section{CONCLUSION}

The results of this study prove that the model proposed in this study states that there is a match between the data in the field and the theory. This research model explains how technology acceptance behavior is shaped by perceptions of the ease and usefulness of a technology. The sample of this study was online HR training participants during the covid-19 pandemic. This is still rarely investigated because so far HRM training has been carried out offline because it will experience many obstacles if it is done online. However, the results of this study prove that technology acceptance behavior will be achieved no matter how difficult the circumstances are.

\section{SUGGESTION}

This study has suggestions in several ways, including the research sample. HRM training participants are conducted online in order to maintain their attitude towards technology, so that they can still use technology in any form, and for any needs without having to worry about difficulties in technology.

Researchers hope that HRM training institutions will be more creative in developing good applications for use in HRM training. In addition, the application can be perceived as easy to use and well utilized by users. When HRM training can be done online, it will make the training costs cheaper and the training more quality.

Meanwhile, for further research, researchers can examine external variables outside the technology acceptance model that has been studied in this study. The next researcher can see about how the influence of perceived behavioral control and subjective norms in much of the previous literature has also been studied. 


\section{BIBLIOGRAPHY}

Adam., Desnis., Ryan, N., \& Peter, T. (1992). Perceived of Uselfulness, Ease of Use, and Usage of Information Technology: A Replication. Managemen Infromation System. Quartely Vol. 21/3.

Alharbi,S.,\& Drew,S.(2019).The Role of Self-efficacy in Technology Acceptance. Springer Nature Switzerland. Page: 1142-1150. DOI: https://doi.org/10.1007/978-3-030-02686-8_85

Azwar, S. (2013). Metode penelitian. Yogyakarta : Pustaka pelajar

Davis, F.D. (1989).Perceived usefulness, perceived ease of use, and user acceptance Of information technology. MIS Quarterly, Vol. 13(3), Page: 319-340

Devi, N.N.S.,\& Suartana,I.W.(2014). Analisis Technology Acceptance Model (Tam) Terhadap Penggunaan Sistem Informasi Di Nusa Dua Beach Hotel \& SPA. EJurnal Akuntansi Universitas Udayana, Page: 167-184

Fatmawati.(2015). Technology Acceptance Model (Tam) Untuk Menganalisis Penerimaan Terhadap Sistem Informasi Perpustakaan. Jurnal Iqra, Volume 09(1)

Ferdinand, A. (2000). Structural Equation Modelling dalam Penelitian Manajemen. Semarang: Penerbit Universitas Diponegoro

Handayani, W.B.,\& Harsono, M.(2016). Aplikasi Technology Acceptance Model (Tam) Pada Komputerisasi Kegiatan Pertanahan. Jurnal Economia, Volume 12(1)

Ibrahim, R., Leng, N.S,. Yusoff,R.C.M., Samy, G.N., Masrom, S., \& Rizman, Z.I.(2017). E-Learning Acceptance Based On Technology Acceptance Model (TAM). Journal of Fundamental and Applied Sciences, ISSN 1112-9867

Igbaria, M. (1994). An Examination of The Factors Contributing to Micro Computer Technology Acceptance. Journal of Information System

Jogiyanto, H.M.(2007). Sistem Informasi Keperilakuan.Yogyakarta : Penerbit Andi Klopping, I.M. and E. McKinney. (2004). Extending the Technology Acceptance Model and Task-Technology Fit Model to Consumer E-Commerce. Information Technology, Learning, and Performance Journal. Vol. 22(1), Page: 35-47

Lee., Hsieh.,\& Ma. (2011). A model of organizational employees' e-learning systems acceptance. Knowledge-Based Systems. Page: 355-366

Malhotra, Y., \& Galletta, D.F. (1999). Extending the Technology Acceptance Model to Account for Social Influence: Theoritical Bases and Empirical Validation. Proceedings of the 32nd Hawaaii International Conference on System Sciences

Nasir,M.(2013).Evaluasi Penerimaan Teknologi Informasi Mahasaiswa di Palembang Menggunakan Model UTAUT.Seminar Nasional Apikasi Teknologi Informasi.ISSN:1907-5002

Peregrina, A.F., Hernández, G.A., \& Miguel, P.F.J. (2014), "Behavioral Intention, Use Behaviour and The Acceptance of Electronic Learning Systems:Differences Between Higher Education and Lifelong Learning.Computers in Human Behaviour.Vol. 34, Page: 301-314

Prawiradilaga, D,S., Ariani, D., \& Handoko, H.(2013). Mozaik Teknologi Pendidikan E-learning. Jakarta : Kencana

Saade, R., George, N., Fassil., \& Tan, W. (2007). Viability of the "Technology Acceptance Model" in Multimedia Learning Environment: A Comparative Study. Interdiciplinary Journal of Knowledge and Learning Objects. Volume 


\section{3, Page :175}

Sayakti, F., \& Putarta, P.(2016). Penerapan Technology Acceptance Model (Tam) Dalam Pengujian Model Penerimaan Sistem Informasi Keuangan Daerah. Jurnal Manajemen Teori dan Terapan. Vol 9(3)

Scherer R., Siddiq, F., \& Tondeur J.(2018). The technology acceptance model

(TAM): A meta-analytic structural equation modeling approach to explaining teachers' adoption of digital technology in education, Computers \& Education, doi: https://doi.org/10.1016/j.compedu.2018.09.009.

Siregar, K.R.(2011). Kajian Mengenai Penerimaan Teknologi dan Informasi Menggunakan Technology Accaptance Model (TAM). Rekayasa, Vol 4(1)

Straub, D.,Limayem, M.,Evaristo,E.K (1995) Measuring System Usage: Implications for IS Theory Testing.Management Science,41(8):1328-1342. http://dx.doi.org/10.1287/mnsc.41.8.1328

Tangke.,\& Natalia. (2004). Analisa Penerimaan Penerapan Teknik Audit Berbantuan Komputer (TABK) dengan Menggunakan Technology Acceptance Model (TAM) pada Badan Pemeriksaan Keuangan (BPK) RI. Jurnal Akuntansi dan Keuangan. Vol. 6(1), Page: 10-28

Tarhini., Hone., \& Liu. (2013). User Acceptance Towards Web-based Learning Systems: Investigating the role of Social, Organizational and Individual factors in European Higher Education . Procedia Computer Science. Page : $189-197$

Teo., \& Timothy. (2011). Technology Acceptance in Education: Research and Issues. Netherlands: Sense Publishers

Teo, T., \& Zhou, M. (2014). Explaining the intention to use technology among university students: a structural equation modeling approach. J Comput High Educ. DOI 10.1007/s12528-014-9080-3

Venkatesh,.,V., \& Davis., Fred.(2000). A Theoritical Extension of the Thechnology Acceptance Model: Four Longitudinal Field Studies. Management Sciences. Vol. 46(2), Page :186-204.

Widhiarso, W.(2011).Uji Hipotesis Komparatif.Yogyakarta : FP. UGM 